\title{
Comparative study between surgical techniques (manual small incision versus phacoemulsification) for cataract surgery
}

\section{Estudio comparativo entre técnicas quirúrgicas (incisión manual pequeña frente a facoemulsificación) para la cirugía de catarata}

\author{
Carla R. Robles-Gutiérrez ${ }^{1 *}$, Mariana Moctezuma-Dávila², Horacio A. Meza-Velarde ${ }^{1 \dagger}$, \\ Araceli Martínez-Castrellón ${ }^{1}$, Martha G. Rangel-Charqueño ${ }^{1}$, Aldanely Padrón-Salas ${ }^{1}$ and \\ Gustavo S. Moctezuma-Bravo ${ }^{3}$
}

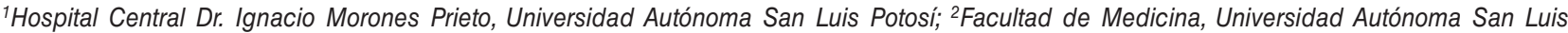
Potosi; ${ }^{3}$ Hospital General Zona No.50, IMSS. San Luis Potosí, Mexico. ${ }^{\dagger}$ Deceased 29 September 2017

\begin{abstract}
Cataract surgery is practiced worldwide. Objective: To determine the postoperative results of visual acuity, endothelial cell loss and posterior capsule opacity between two cataract surgery techniques. Type of Study: Randomized, controlled, double-blind clinical trial (ECCE), in patients with cataract, with an 18-month follow-up. Exclusion Criteria: Patients with proliferative diabetic retinopathy, macular edema, amblyopia and glaucoma. Elimination Criteria: Patients that required a change in the surgical technique or that did not complete follow up. Sample Size: 75 patients according to Peduzzi and Frank studies. Bioethical Considerations: Study approved by the Research and Bioethics Institutional Committee. Following the Helsinki, Code of Nuremberg and General Law of Health guidelines, all the patients signed an informed consent form. Data are described with measures of central tendency, dispersion and proportions. Statistical analysis used Chi-square, Fisher's exact test, Student's $t$, ANOVA and linear regression tests. Results: 57 patients were included: 35 women and 22 men, 26 diabetics and 8 with non-proliferative diabetic retinopathy. 34 patients were treated with manual small incision (MSI) and 23 with phacoemulsification (PHACO). The average age group was 70.4 and 67.9 years, respectively. Visual acuity and posterior capsule opacification were statistically significant for both techniques. A decrease in endothelial cell count was observed for the two techniques, but a greater change in the keratometry axis was present in IMP. In addition, endothelial polymorphism and corneal pachymetry were increased in FACO. Conclusion: MSI is not inferior to PHACO.
\end{abstract}

Key words: Surgery. Cataract. Phacoemulsification. Manual small incision. Controlled clinical trial.

\section{Resumen}

La cirugía de catarata se practica mundialmente. Objetivo de estudio: Determinar los resultados posquirúrgicos de agudeza visual, pérdida de células endoteliales y opacidad de la cápsula posterior, entre dos técnicas quirúrgicas que corrigen la catarata. Tipo de estudio: Ensayo clínico controlado, aleatorizado y doble ciego, en pacientes con diagnóstico de catarata, con seguimiento a 18 meses. Criterios de exclusión: Pacientes con retinopatía diabética proliferativa, edema macular, ambliopía y glaucoma. Criterios de eliminación: Pacientes que requirieron cambio de técnica quirúrgica y pacientes que no acudieron a

Correspondence:

${ }^{*}$ Carla R. Robles-Gutiérrez

C. Barrio de Tlaxcala 116

Col. San Pedro

Date of reception: 27-12-2017

Available online: $17-09-2018$

San Luis Potosí, Mexico

Date of acceptance: 05-07-2018

Rev Mex Oftalmol (Eng).2018;92(5):207-214

E-mail: carla_rrg@ hotmail.com

DOI: 10.24875/RMOE.M18000026

www.rmo.com.mx

2604-1731/O 2018 Sociedad Mexicana de Oftalmología Published by Permanyer México SA de CV. This is an Open Access article under the CC BY-NC-ND license (http://creativecommons.org/licenses/by-nc-nd/4.0/). 
su seguimiento. Tamaño de la muestra: 75 pacientes según estudios de Peduzzi y Frank. Consideraciones bioéticas: estudio aprobado por el Comité de Investigación y Bioética Institucional Hospitalaria, siguiendo lineamientos de Helsinki, código de Núremberg y Ley General de Salud, donde cada paciente firmó su consentimiento informado. Análisis de datos: Datos descritos con medidas de tendencia central, dispersión y proporciones. Análisis estadístico: empleó Chi cuadrada, prueba exacta de Fisher, $T$ de Student, Anova y regresión lineal. Resultados: Se incluyeron finalmente 57 pacientes, 35 mujeres y 22 hombres, 26 diabéticos y 8 con retinopatía diabética no proliferativa. Tratados 34 con incisión manual pequeña (IMP) y 23 con facoemulsificación (FACO), su edad promedio grupal fue de 70.4 y 67.9 años, respectivamente. Las variables agudeza visual y opacidad de la cápsula posterior resultaron estadísticamente significativas para ambas técnicas. El resultado fue: disminución del conteo de células endoteliales para las dos técnicas, mayor cambio del eje queratométrico en la IMP y mayor polimorfismo de endotelio y paquimetría corneal en la FACO. Conclusión: La IMP no es inferior a la FACO.

Palabras clave: Cirugía. Catarata. Facoemulsificación. Incisión manual pequeña. Ensayo clínico controlado.

\section{Introduction}

Cataract, or lens opacity, is the main cause of reversible blindness ${ }^{1,2}$. Globally, there are approximately 37 million people with blindness ${ }^{1}$, with 515 thousand people with blindness estimated in Mexico, from which $60 \%$ are due to cataracts, and with an annual addition of 50 to 60 thousand new cases $^{3}$.

In ophthalmology, cataract extraction is the most practiced surgery worldwide, and it can be by manual small incision (MSI), extracting the nucleus through a $6.5 \mathrm{~mm}$ sclerocorneal tunnel; by phacoemulsification (PHACO) through a $3 \mathrm{~mm}$ incision and using ultrasound that emulsifies the cataract; and extracapsular cataract extraction (ECCE), through a $12 \mathrm{~mm}$ incision. The most used technique is PHACO, followed by ECCE and finally MSI. The latter is carried out more frequently in developing countries because of its advantages of being more economical since it not uses ultrasound; also, it allows the use of rigid or foldable lens ${ }^{4,5}$ and it is not inferior to PHACO ${ }^{6,7,8}$. However, the three techniques improve patients' quality of life by allowing visual recovery. $\mathrm{MSI}$ and $\mathrm{PHACO}^{9}$ do not use sutures and require less time for visual rehabilitation. The average time of surgery in MSI is 8 minutes and 35 seconds, while in PHACO it is 15 minutes and 30 seconds $^{4}$. However, the learning curve for PHACO is longer ${ }^{2,4,9}$. The present clinical study using MSI and PHACO techniques for the surgical correction of cataract with a follow-up of eighteen months, aims to compare the results of best-corrected visual acuity (BCVA), the difference in endothelial cell loss and posterior capsule opacity (PCO).

\section{Objective}

To determine if MSI has similar postoperative results compared to PHACO.

\section{Material and methods}

\section{Study design}

Randomized, double blind, controlled clinical trial (RCT), performed from May 1, 2013 to March 31, 2015, at the Hospital Dr. Ignacio Morones Prieto in San Luis Potosí, Mexico.

\section{Inclusion criteria}

Patients with cataract diagnosis who are candidates for surgical management, with a visual acuity (VA) $<20 / 40$.

\section{Exclusion criteria}

Patients with advanced proliferative diabetic retinopathy, macular edema, age-related macular degeneration, amblyopia, glaucoma, patients without endothelial cell counts or with outdated counts (earlier than 3 months before surgery) and those who do not agree to participate in the study.

\section{Elimination criteria}

Patients requiring a change in the surgical technique, with macular pathology detected after cataract extraction and patients who do not attend follow-up consultations.

\section{Sample size}

Between 40 and 80 repetitions considering the final corrected VA (surgical technique), the difference in endothelial cell reduction (surgical technique) and posterior capsule opacity (surgical technique) for studies that use regression models according to Peduzzi, Feinstein and Frank ${ }^{10,11}$. Variables: sex, age, cataract or lens 
opacity measured by an international standardized scale: Lens Opacities Classification System (LOCS); which evaluates by six slit lamp images the nucleus color (NC1-6), opalescence (NO1-6), and with five images, cortical cataract (C1-5) and subcapsular cataract (P1-5); VA: visual acuity measured with and without correction (logMAR); endothelial cell count: endothelial cell number obtained by a manual technique using specular microscopy cells $/ \mathrm{mm}^{2}$; PCO: degree of posterior capsule opacity at 3 and 18 months after surgery, according to the LOCSIII P1-5 scale; keratometry (Ktm): average of corneal diopters in the central $3 \mathrm{~mm}$; refraction or spherical equivalent (SE): Corrected VA achieving maximum visual capacity represented by its SE: $E+1 / 2 C$; intraocular pressure (IOP) starting from $1 \mathrm{mmHg}$, normal $10-21 \mathrm{mmHg}$.

\section{Bioethical considerations}

Study approved by the Research and Bioethics Committee of the Hospital Central Dr. Ignacio Morones Prieto, with registration number 55-13. The study followed the Helsinki guidelines, the Nuremberg Code and the General Health Law. Each patient signed an informed consent form, the information was managed as confidential and his or her identity was maintained as anonymous.

\section{Material resources}

Stellaris-pc phacoemulsifier, B\&L. Mode A US, Alcon; specular microscope, Konan; ophthalmological microscope, Leica; visual acuity projector, Huvitz; Goldman tonometer, Keeler; PMMA lens, Acuity; foldable hydrophilic lens, B\&L; ophthalmological instruments of the Hospital Central Dr. Ignacio Morones Prieto; and laptop, HP.

\section{Sampling technique}

With a list of random numbers to assign patients to surgery A or B. Standardization of the intervention: an initial complete ophthalmological examination was performed, considering diabetes mellitus history and the presence of proliferative or non-proliferative diabetic retinopathy. Prior to surgery, uncorrected visual acuity (UCVA) and pinhole VA at $3 \mathrm{~m}$ was taken with a projector calibrated in logMAR, refraction and $\mathrm{Ktm}$ with an autorefractor keratometer calibrated with the SE and $\mathrm{Ktm}$. IOP average taken with calibrated Goldman tonometer. Specular microscopy taken with a manual technique (one day before surgery). The surgical procedure was carried out as outpatient surgery. All operations with the manual small incision technique $(\mathrm{MSI})^{2}$ were performed by one surgeon, Dr. Meza $\left(3^{*}\right)$, phacoemulsification (PHACO) ${ }^{12}$ was performed by another surgeon, Dr. Martinez $\left(4^{*}\right)$. In the initial postoperative period, patients were treated with antibiotic and topical steroidal anti-inflammatory drops. They were evaluated seven and thirty days after surgery with VA and IOP registration. In the third month, BCVA, IOP, Ktm, PCO (according to LOCS III) and specular microscopy were recorded. These tests were performed with a specular microscope, Konan, CCP-3100 visual acuity projector, Huvitz, KR-3000 autorefractor keratometer, Topcon and Goldman applanation tonometer, Keeler. After 18 months of follow-up, we evaluated the following: UCVA/ BCVA and PCO.

\section{Data analysis}

Quantitative variables were described with central tendency and dispersion measures; qualitative variables with proportions; statistical analysis with STATA v. $12^{\circledR}$ package, considering statistical significance $p<0.05$, and using Chi square, Fisher's exact test, Student's t-test, Anova and linear regression.

\section{Results}

Initially, the study included 75 patients. Later, the study excluded eighteen patients: nine because surgery was not performed on the scheduled day due to systemic alterations, lack of surgical time or lack of surgery supplies. Five were lost in follow-up. Two because of a decision of changing the surgery to extracapsular extraction: one due to hyphema that required anterior chamber wash and another because of macular edema not detected preoperatively due to lens opacity. Finally, 57 eyes of different patients were included in the study: 34 of them underwent MSI and 23 PHACO.

The patients in the MSI group had an average age of 70.4 years, with a standard deviation (SD) of 12.3, sixteen patients had diabetes and, of these, five had non-proliferative diabetic retinopathy (NPDR). Twenty-two were female, and there were 17 right eyes and 17 left eyes.

The patients in the PHACO group had an average age of 67.9 years, with a SD of 14.2 , ten had diabetes mellitus and three of them had NPDR. Thirteen were female and there were 13 right eyes and 10 left eyes (Table 1). 
Table 1. General data

\begin{tabular}{|l|c|c|}
\hline \multirow{2}{*}{} & \multicolumn{2}{|c|}{ Patients and surgery } \\
\cline { 2 - 3 } & MSI & PHACO \\
\hline Female & 34 & 23 \\
\hline Male & $22(64.7 \%)$ & $13(56.5 \%)$ \\
\hline EYE & $12(35.3 \%)$ & $10(43.5 \%)$ \\
\hline Right & 34 & 23 \\
\hline Left & $17(50 \%)$ & $13(56.5 \%)$ \\
\hline DIABETIC & $17(50 \%)$ & $10(43.5 \%)$ \\
\hline D w/o NPDR & 21 & 13 \\
\hline D w/NPDR & $16(47 \%)$ & $10(43 \%)$ \\
\hline
\end{tabular}

Manual small incision (MSI), Phacoemulsification (PHACO), Diabetics without Nonproliferative Diabetic Retinopathy (D w/o NPDR). Diabetics with Nonproliferative Diabetic Retinopathy (D w/NPDR).

With the statistical analyses used, non-statistically significant variables with the MSI technique between the initial and final average were SE +0.10 and -0.99 , respectively, $\mathrm{Ktm} 43.83$ and 43.84 , and intraocular pressure 13.91 and 12.36. For PHACO, they were SE of -0.07 and -0.60 , $\mathrm{Ktm} 43.53$ and 43.37 and IOP 12.43 and 11.86, as initial and final averages, respectively. The variable "initial VA" at seven, thirty, ninety and five hundred forty postoperative days was statistically significant for both the MSI technique and the PHACO technique. Other variables that also showed a significant statistical difference for both techniques were the endothelial cell count, keratometry axis and PCO (Table 2). We highlight the decrease in endothelial cell count with both techniques, the greater change of the keratometry axis with $\mathrm{MSI}$ and the greater endothelial polymorphism and corneal pachymetry with PHACO.

Regarding lens hardness, cataracts were divided as soft (NO1-NO3) or hard (NO3.1-NO6), according to LOCS III. Eighteen soft cataracts were operated with MSI and 19 with PHACO, whereas 16 hard cataracts were operated with $\mathrm{MSI}$ and four with PHACO. From the results obtained, no correlation was found between lens hardness and final VA with each technique (Table 3). For the variables VA before surgery, patients without diabetes mellitus and patients with mild diabetic retinopathy without macular disease, the worst VA was found at the beginning of the study in diabetics without diabetic retinopathy, with an average vision of 1.61 logMAR, followed by non-diabetics, with an average of 0.93 logMAR, and, finally, diabetics with mild diabetic retinopathy without macular involvement, with an average of $0.84 \log M A R$, observing a statistically significant value $(p=0.0298)$. Variables: final visual acuity and variable visual acuity prior to surgery showed an $r 2<0.001(p=0.968)$; therefore, there is no correlation.

Statistical analyses of the statistically significant variables is shown in figures. 1, 2, 3 and 4 .

\section{Discussion}

VA after cataract surgery is the result of several factors, such as keratometry readings, corneal axis, tear film quality and axial length of the eyeball, which in turn influence the type of intraocular lens to be used.

In our study, the variable "final VA" in the postoperative follow-up at 3 months was similar in MSI and PHACO groups, with BCVA averages of 0.21 logMAR for both groups. There are reports that show similar results $2,6,7,8,13$. However, in these studies, PHACO groups showed a better-uncorrected VA compared to MSI groups, but without statistically significant differences. In addition, visual results between diabetic and non-diabetic patients were similar, showing that surgery is indicated in patients without active diabetic retinopathy.

One study ${ }^{14}$ compared $\mathrm{MSI}$ and PHACO regarding final VA, and found no statistically significant differences between both groups. The VA results up to six weeks after cataract surgery, with PHACO as gold standard compared to $\mathrm{MSI}$, using ECCE, found visual results better or equal to 20/60 in the PHACO group, with a statistically significant difference ${ }^{9}$.

Cataract surgery is one of the factors that cause endothelial cell loss and polymorphism is the best indicator of endothelial stress, measured by the hexagonality (\% of normal hexagonality $>60)$ and variation in cell size of the coefficient of variation (CV) (normal CV figure $<33 \%)^{6,14,15,16}$. After cataract surgery, endothelial cells elongate and move to maintain endothelial continuity, generating changes in cell density, hexagonal morphology and cell size variation.

This surgical trauma leads to cell loss with a decrease of hexagonal morphology and an increase in cell size in an attempt to replace the lost cells, conditioning an increase in the CV and a decrease in hexagonality, which manifests as an increase in polymegathism and polymorphism. In our study, a greater polymorphism was found in PHACO compared to MSI, which was statistically significant $(p=0.044)$; however, no differences were found regarding polymegathism. This cellular loss can lead to prolonged corneal edema, which in 
Table 2. Average Results by surgical technique

\begin{tabular}{|c|c|c|c|c|c|c|}
\hline Column1 & MSI $(n=34)$ & $\begin{array}{l}\text { MSI } P \text { value } \\
\text { (Initial and final } \\
\text { comparison) }\end{array}$ & PHACO (n = 23) & $\begin{array}{l}\text { PHACO } P \text { value } \\
\text { (Initial and final } \\
\text { comparison) }\end{array}$ & Total (n = 57) & $\begin{array}{c}\text { P value } \\
\text { (Technique } \\
\text { comparison) }\end{array}$ \\
\hline $\begin{array}{l}\text { VA } \\
\text { Initial } \\
1 \text { week } \\
1 \text { month } \\
3 \text { months }\end{array}$ & $\begin{array}{l}1.27 \\
0.52 \\
0.43 \\
0.25\end{array}$ & $\begin{array}{l}-0.001 \\
-0.001 \\
<0.001\end{array}$ & $\begin{array}{l}0.93 \\
0.46 \\
0.36 \\
0.17\end{array}$ & $\begin{array}{c}0.012 \\
0.001 \\
<0.001\end{array}$ & $\begin{array}{l}1.13 \\
0.5 \\
0.4 \\
0.21\end{array}$ & $\begin{array}{c}0.905 \\
0.68 \\
0.749 \\
0.905\end{array}$ \\
\hline $\begin{array}{l}18 \text { months } \\
\text { w/o C }\end{array}$ & 0.49 & $<0.001$ & 0.44 & $<0.001$ & 0.47 & 0.274 \\
\hline $\begin{array}{l}18 \text { months } \\
\mathrm{w} / \mathrm{C}^{* *}\end{array}$ & 0.28 & $<0.001$ & 0.26 & $<0.001$ & 0.27 & 0.385 \\
\hline Difference & -1.01 & & -1.05 & & -0.91 & 0.169 \\
\hline $\begin{array}{l}\text { Axis } \\
\text { Initial } \\
\text { Final* } \\
\text { Diff }\end{array}$ & $\begin{array}{c}80.48 \\
120.46 \\
-42.84\end{array}$ & $\begin{array}{l}0.002 \\
0.002\end{array}$ & $\begin{array}{c}103.86 \\
99.88 \\
-1.05\end{array}$ & $\begin{array}{l}0.409 \\
0.409\end{array}$ & $\begin{array}{c}90.08 \\
112.32 \\
-26.32\end{array}$ & $\begin{array}{c}0.077 \\
0.937 \\
0.95\end{array}$ \\
\hline $\begin{array}{l}\text { EC } \\
\text { Initial } \\
\text { Final* } \\
\text { Diff }\end{array}$ & $\begin{array}{r}2667.08 \\
2462.23 \\
-146.02\end{array}$ & $\begin{array}{l}0.014 \\
0.014\end{array}$ & $\begin{array}{c}2644.04 \\
2431.43 \\
-179.6\end{array}$ & $\begin{array}{l}0.007 \\
0.007\end{array}$ & $\begin{array}{c}2644.47 \\
2449.8 \\
-159.57\end{array}$ & $\begin{array}{c}0.815 \\
0.61 \\
0.222\end{array}$ \\
\hline $\begin{array}{l}\text { Hexagonality } \\
\text { Initial } \\
\text { Final } \\
\text { Diff }\end{array}$ & $\begin{array}{c}42.32 \\
39.7 \\
-2.61\end{array}$ & $\begin{array}{l}0.63 \\
0.63\end{array}$ & $\begin{array}{c}42.3 \\
38.34 \\
-3.95\end{array}$ & $\begin{array}{l}0.044 \\
0.044\end{array}$ & $\begin{array}{l}42.31 \\
39.15 \\
-3.15\end{array}$ & $\begin{array}{l}0.504 \\
0.742 \\
0.729\end{array}$ \\
\hline $\begin{array}{l}\text { Pachymetry } \\
\text { Initial } \\
\text { Final } \\
\text { Diff } \\
\text { PCO** }\end{array}$ & $\begin{array}{c}531.61 \\
532.08 \\
0.47 \\
69.23\end{array}$ & $\begin{array}{l}0.48 \\
0.48\end{array}$ & $\begin{array}{c}540.43 \\
557.86 \\
17.43 \\
30.77\end{array}$ & $\begin{array}{l}0.162 \\
0.162\end{array}$ & $\begin{array}{c}535.17 \\
542.49 \\
7.31 \\
100\end{array}$ & $\begin{array}{l}0.212 \\
0.043 \\
0.099 \\
0.423\end{array}$ \\
\hline
\end{tabular}

Manual small incision (MSI), Phacoemulsification (PHACO). Visual acuity (VA), Spherical equivalent (SE), Keratometry (Ktm), Intraocular pressure (IOP), Endothelial cells (EC), Posterior capsule opacity (PCO). Difference (Diff). *Follow-up to six months. **Follow-up to 18 months. MSI $n=26$, PHACO $n=17$.

Table 3. Lens hardness analysis by surgical technique

\begin{tabular}{|l|c|c|c|c|c|}
\hline Hardness & MSI & PHACO & Total & Log Mar VA* & Final VA average P* \\
\hline Soft & $18(49 \%)$ & $19(51 \%)$ & $37(65 \%)$ & 0.21 and 0.30 & 0.021 \\
\hline Hard & $16(80 \%)$ & $4(20 \%)$ & $20(35 \%)$ & 0.18 and 0.13 & 0.021 \\
\hline
\end{tabular}

Final VA average $\mathrm{P}^{*}$; Final VA average with $P$ value, Soft: LOCS III (N01-NO3). Hard: LOCSIII (NO3.1-NO6)

severe cases causes corneal decompensation associated with low visual acuity $6,13,17,18$. An ECCE ${ }^{6}$ study in 200 patients compared the percentage of endothelial cell loss with PHACO vs. MSI, and found a similar endothelial cell loss between both surgeries (MSI and PHACO), showing that after surgical trauma there is a statistically significant decrease in the number of cells, as observed in our study (MSI, $p=0.014$; PHACO, $p=0.007)$. Another study compared the percentage of endothelial cell loss after ECCE, MSI and PHACO, showing decreases of $4.72,4.21$ and $5.41 \%$, respectively, with no statistical significance.

In postoperative studies at 3-months in populations without history of ocular pathology, cataract surgery decreased the density of endothelial cells, increased the coefficient of variation and decreased the percentage of hexagonal cells $\mathbf{s}^{13,19,20}$. The comparison of percentage of endothelial cell loss between PHACO and MSI 


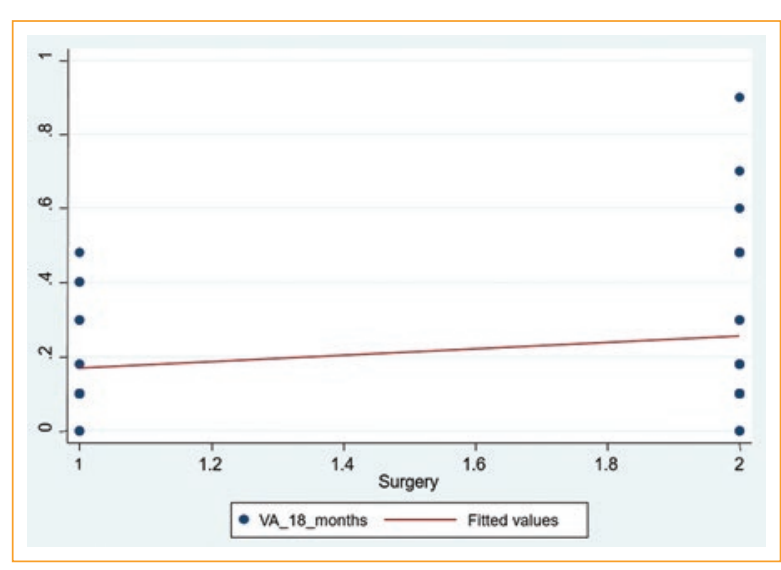

Figure 1. Linear regression analysis between variables: final VA and type of surgical technique. An r2 of 0.046 was obtained $(p=0.108)$, indicating no correlation. VA: visual acuity.

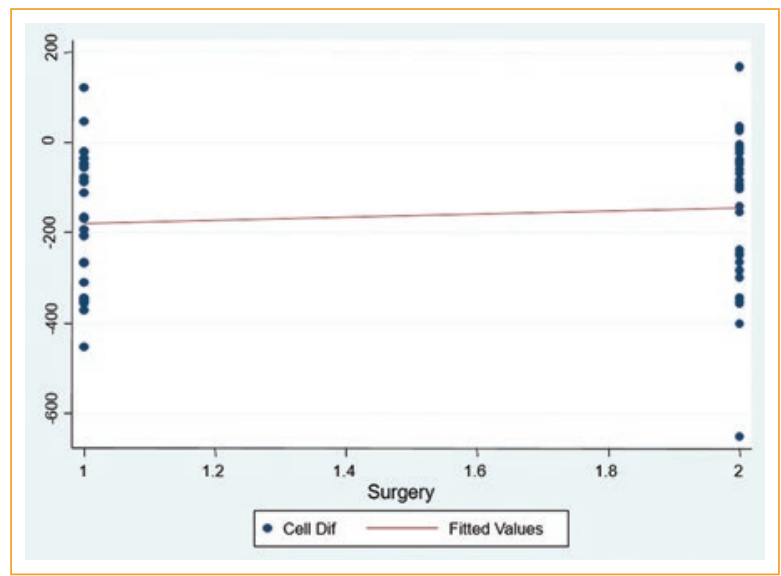

Figure 2. Linear regression analysis between endothelial cell loss and surgical technique. An r2 of 0.010 was obtained $(p=0.445)$, indicating no correlation.

at 6 weeks postoperatively, showed a loss of $15.5 \%$ and $15.3 \%$, respectively, without statistical significance ${ }^{6,18}$.

In our study, endothelial cell counts at 3 months of follow-up showed an average of 146 cells $(7.5 \%)$ for MSI and 179 cells (6.8\%) for PHACO, without statistical significance.

A three-month postoperative study in diabetic and non-diabetic patients undergoing MSI and PHACO, found a higher rate of endothelial cell loss in the group of diabetic patients: $6.2 \%$ vs. $1.4 \%$ in non-diabetic patients, related to the increase in the degree of the cataract and duration of surgery; however, this difference was not statistically significant ${ }^{13}$.

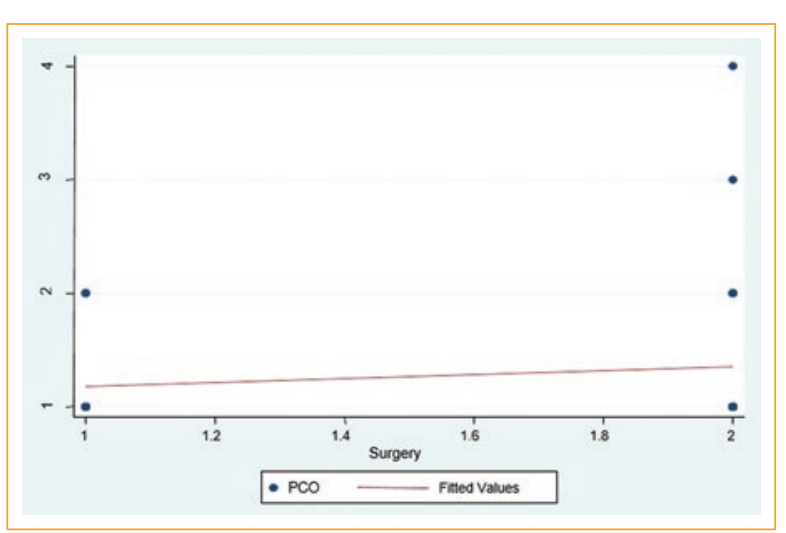

Figure 3. Linear regression analysis between posterior capsule opacity and surgical technique. No correlation was found ( $r 2$ value $0.022(p=0.265)$ ). These results were similar at three months and at eighteen months of follow-up. PCO: posterior capsule opacity.

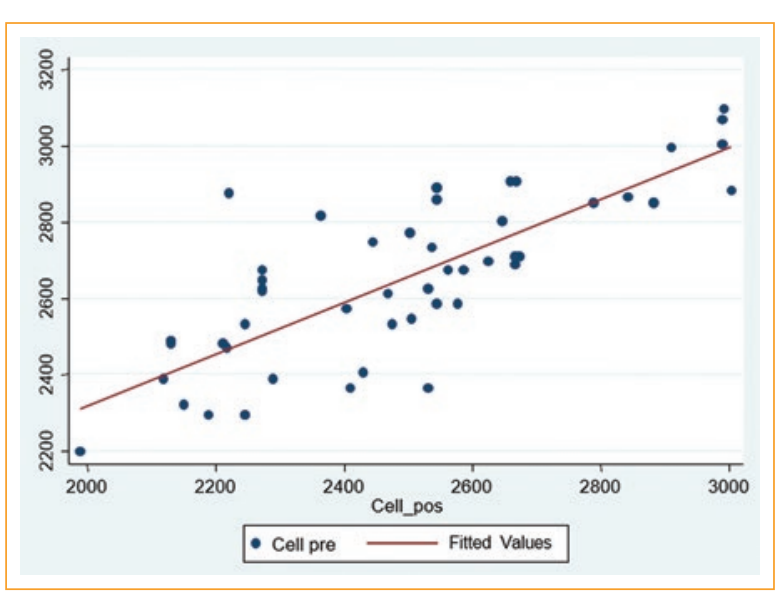

Figure 4. Linear regression analysis between the number of endothelial cells after and before surgery. An r2 of 0.645 was obtained $(p<0.001)$, meaning that the number of cells after surgery depends on the number of cells before surgery, but it is not related to the type of surgery.

PCO is a frequent complication after cataract surgery, with an incidence between 2 and $15 \%$ at one year and between 2 and $63 \%$ at 3 years after phacoemulsification. A study that investigated the incidence and risk factors for $\mathrm{PCO}^{21}$ with a 3-year follow-up, concluded that surgeons in training, the use of one- and three-piece hydrophilic lenses and hydrophobic lenses without sharp edges, compared to hydrophobic acrylic lenses with square edges, are predisposing factors for PCO. Ruit ${ }^{22}$ compared the occurrence of $\mathrm{PCO}$ in $\mathrm{MSI}$ and PHACO at 6 months of postoperative follow-up, and 
found $26.1 \%$ of $\mathrm{PCO}$ in $\mathrm{MSI}$ and $14.6 \%$ in PHACO, with a greater degree of opacity in MSI.

In our study, the degree of posterior capsule opacity was similar in both groups. However, we observed a greater degree of opacity in the MSI group, although a thorough analysis is necessary that considers other known predisposing factors of PCO such as the type and design of intraocular lens, age and sex, among others ${ }^{21}$. For the purpose of our study, PCO related only to the surgical technique used (MSI or PHACO).

The SE, Ktm and $\mathrm{Ktm}$ axis were measured before and after surgery. The SE average was $0.60 \mathrm{D}$ and $0.99 \mathrm{D}$ for $\mathrm{MSI}$ and PHACO, respectively, without a statistically significant difference. $\mathrm{Ktm}$ in both groups practically remained the same compared to pre-surgical values. Regarding the axis, there was a statistically significant change of 42.84 degrees compared to the pre-surgical axis in MSI $(p=0.002)$. This could explain the uncorrected VA improvement (not statistically significant) in the PHACO group.

Another important finding was pachymetry. A study published in 2005 showed that patients with an endothelial count before surgery of $640 \mu \mathrm{m}$, Fuchs endothelial dystrophy and the presence of iridocorneal-endothelial syndrome were at increased risk of corneal decompensation after surgical trauma. Therefore, they recommended triple procedures for these patients $\mathrm{s}^{6,13,23}$. In our study, we compared pachymetry before surgery and at 3 months, but we did not found a statistically significant difference between the initial and final pachymetry between both groups, although we found that patients in the PHACO group had a statistically significant increase $(p=0.043)$ in pachymetry compared to the MSI group.

We expected that hard cataracts would achieve better results with $\mathrm{MSI}$ and that soft cataracts would have better results with PHACO, however, this was not the case. The IOP did not show statistically significant variations after surgery compared to IOP before surgery for both groups.

\section{Conclusion}

Although our study has a small number of patients, it showed similar results to those published in the literature. Cataract surgery with $\mathrm{MSI}$ is not inferior to PHA$\mathrm{CO}$ in terms of VA, endothelial cell loss, or posterior capsule opacity and the differences between techniques were not statistically significant.
BCVA at 3 months was very similar in both groups, with a similar SE. The keratometry axis in the MSI group showed statistically significant differences.

PCO was similar in both groups, however, the highest degree was observed in the MSI group, but the difference was not statistically significant.

Surgery results in diabetic and non-diabetic patients did not differ between techniques; there were no IOP variations between groups.

Therefore, this study shows that the MSI technique provides acceptable visual results, in case of not having a phacoemulsification machine or any of the supplies required to perform PHACO. An adequate selection of the case is essential, with a careful surgery and follow-up to obtain a good result, regardless of the technique used.

\section{Ethical disclosures}

Protection of human and animal subjects. The authors declare that the procedures followed were in accordance with the regulations of the relevant clinical research ethics committee and with those of the Code of Ethics of the World Medical Association (Declaration of Helsinki).

Confidentiality of data. The authors declare that they have followed the protocols of their work center on the publication of patient data.

Right to privacy and informed consent. The authors have obtained the written informed consent of the patients or subjects mentioned in the article. The corresponding author is in possession of this document.

\section{Conflicts of interest}

The authors declare that they have no conflict of interest, since there is no financial or personal relationship at the time of writing or submitting the article with persons or institutions that could give rise to conflicts of interest related to the article submitted for publication.

\section{References}

1. World Health Organization. Blindness and Visual Impairment. Updated 2006. Disponible en: http://www.who.int/features/factfiles/vision/04 en.html

2. Rengaraj V, David C, Radhakrishnan M, Kenia H, Pariskshit G,Sabyasachi S. Manual Small Incision Cataract Surgery: A Review. Asia Pacific Academy of Ophthalmology 2012;1: 113Y119.

3. Barojas W, SanJuan E, Ortega G. Reporte de una campaña quirúrgica de catarata Instituto Nacional de Salud. Rev Mex de Oftalmol. 2010;84(2):91-5.

4. Parikshit G, Madan D, Praveen K, Nirmalm D. Why Do Phacoemulsification? Manual Small-Incision Cataract Surgery Is Almost as Effective, but Less Expensive. Ophthalmology. 2007;114:965-68. 
5. Amar A, Dhivya A. Cost-effectiveness of cataract surgery. Curr Opin Ophthalmol. 2011,22:15-8.

6. Parikshit G, Prachi A, Sucheta K, Rahul D, Shilpa J, Madan D. Comparison of endothelial cell loss after cataract surgery: Phacoemulsification versus manual small-incision cataract surgery. Six-week results of a randomized control trial. J Cataract Refract Surg. 2010;36:247-53.

7. Rohit A, Srivalli K, Ghanshyam P, Virender S. Comparative outcomes of manual small incision cataract surgery and phacoemulsification performed by ophthalmology trainees in a tertiary eye care hospital in India: a retrospective cohort design. BMJ Open. 2012;2:001035-001136.

8. Jia-yu Z, Yi-fan F, Jian-qiu C. Phacoemulsification versus manual smaII-incision cataract surgery for age-related cataract: meta-analysis of randomized controlled trial. Clin Exp Ophthalmol. 2013;41:379-86.

9. Parikshit G, Sucheta K, Krishnaiah S, Rahul D, Shilpa J, Anand P. Safety and Efficacy of Phacoemulsification Compared With Manual Small Incisión Cataract Surgery by a Randomized Controlled Clinical Trial. Ophthalmology. 2005;112:869-74.

10. Peter Peduzzi, John Cocato, Elizabeth Kemper, Theodore R. Holford and Alvan R. Feinstein. A Simulation Study of the Number of Events per Variable in Logistic Regression Analysis. J Clin Epidemiol. 1996; 49(12):1373-9.

11. Frank E. Harrell, Kerry L. Lee, David B. Matchar, and Thomas A. Reichert. Regression Models for Prognostic Prediction: Advantages, Problems, and Suggested Solutions. Cancer Treat Rep. 1985;69(10):1071-7.

12. Ellwein L, Urato C. Use of eye care and associated charges among the Medicare population: 1991-1998. Arch Ophthalmol. 2001;85:822-9.

13. Priya T, Sarada D, Nihal T. Endothelial Cell Loss and Central Corneal Thickness in Patients With and Without Diabetes After Manual Small Incision Cataract Surgery. Cornea. 2011;30:424-8.
14. Sambuddha G, Indranil R, Pradyot N, Dipankar M, Lakshmi K, Subhalakshmi M. Prospective randomized comparative study of macular thickness following phacoemulsification and manual small incision cataract surgery. Acta Ophthalmologica. 2010;88:102-6.

15. Manea G, Stanca H. Specular microscopy and clinical correlations. Ophthalmology. 2011;55(3):22-9.

16. Tuft S, Coster D. The corneal endothelium. Eye. 1990;4(3):389-424.

17. Moschos M, Chatziralli I, Sergentanis T. Viscoat versus visthesia during phacoemulsification cataract surgery: corneal and foveal changes. BMC Ophthalmol. 2011;11:4-7.

18. Rosado N, Natalie A. The changing fate of the corneal endothelium in cataract surgery. Curr Opin Ophthalmol. 2012;23:3-6.

19. Schultz R, Glasser D, Matsuda M. Response of the corneal endothelium to cataract surgery. Arch Ophthalmol.1986;104:1164-9.

20. Ventura A, Walti R, Bohnke M. Corneal thickness and endothelial density before and after cataract surgery. Br J Ophthalmol. 2001;85:18-20.

21. Fong $C$, Mitchell $P$, Rochtchina E, Cugati S, Hong T, Wang J. Three-year incidence and factors associated with posterior capsule opacification after cataract surgery: The Australian Prospective Cataract Surgery and Age-related Macular Degeneration Study. Am J Ophthalmol. 2014;157: 171-9.

22. Ruit S, Tabin G, Chang D. A prospective randomized clinical trial of phacoemulsification vs manual sutureless small-incision extracapsular cataract surgery in Nepal. Am J Ophthalmol. 2007;143:32-8.

23. Seitzman G, Gottsch J, Stark W. Cataract surgery in patiens with Fuchs' corneal dystrophy expanding recommendations for cataract surgery without simultaneous keratoplasty. Ophthalmology. 2005;112:441-6. 